\title{
A REPRESENTAÇÃO DO MILAGRE EM "NATAL NA BARCA" E "O DEFUNTO": DIFERENTES MANIFESTAÇÕES LITERÁRIAS DO INSÓLITO
}

\author{
THE REPRESENTATION OF THE MIRACLE IN "NATAL \\ NA BARCA" AND "O DEFUNTO": DIFERENT LITERARY \\ MANIFESTATIONS OF THE UNUSUAL
}

Ana Cristina Caminha Viana Lopes ${ }^{1}$

Ana Márcia Alves Siqueira²

\begin{abstract}
Resumo: $\mathrm{O}$ presente artigo tem como objetivo realizar uma breve análise comparativa entre os contos "O Defunto" de Eça de Queirós e "Natal na barca" de Lygia Fagundes Telles, ambos marcados pela presença de fenômenos meta-empíricos. Tenciona-se abordar pontos divergentes e convergentes, no tocante às categorias narrativas e aos subgêneros relativos à literatura do insólito, como o fantástico e o maravilhoso cristăo. Por fim, o trabalho visa destacar a relaçâo entre vida, morte e fé, bem como, evidenciar a presença do "milagre" enquanto elemento propiciador do clímax em cada narrativa. Para este intento, será utilizada, principalmente, a contribuiçâo teórica dos estudiosos David Roas, Felipe Furtado e Tzvetan Todorov.
\end{abstract}

Palavras-chave: Literatura fantástica. Maravilhoso cristâo. Insólito. Milagre.

Abstract: The present article compares the short stories "O Defunto" 'The Deceased' by Eça de Queiroz and "Natal na barca" 'Christmas on the Boat' by Lygia Fagundes Telles. Both short stories are marked by the presence of meta-empirical phenomena. The article explores differences and similarities between narrative categories and subgenres pertaining to literature that deals with the unusual, such as the fantastic and the Marvelous Christian, as present in the literary works in question. Lastly, this article aims to emphasize the relationship between life, death and faith, as well as to highlight the presence of the "miracle" as the climax of each narrative. The analysis

1 Licenciatura em Letras pela UFC (2002). Mestrado em Literatura Brasileira pela UFC (2006). E-mail: anacaminha@ufc.br

2 Mestre em Estudos Literários pela UNESP (1998) e doutora em Literatura Portuguesa pela USP (2007). Professora associada do Departamento de Literatura e da Pós-Graduaçấo em Letras da Universidade Federal do Ceará.E-mail: ana.siqueira@ufc.br 
of the short stories is mainly based on the theoretical contributions of scholars David Roas, Felipe Furtado and Tzvetan Todorov.

Keywords: Fantastic literature. The marvelous Christian. The unusual. Miracle.

\section{O EFEITO FANTÁSTICO E O INSÓLITO}

Falar sobre "literatura fantástica" ou, de forma mais expansiva, sobre a literatura do "insólito" constitui sempre desafio inevitável e, no entanto, simultaneamente tentador àqueles que mergulham na leitura de tais narrativas, como mariposas atraídas pela luz. No caso em apreço, a atraçâo seria mais pela eclosâo de sombras misteriosas em meio à luz da nossa realidade. Este desafio reside na rica produçăo dessas modalidades literárias e, principalmente, nas diversas teorias que procuram, a custo, acompanhar tal produçăo.

No rastro dessa trilha, buscamos com o presente trabalho adentrar o universo particular de duas narrativas marcadas pela presença do insólito propiciado pela fé, isto é, o acontecimento milagroso: "Natal na Barca", de Lygia Fagundes Telles, e "O Defunto", de Eça de Queiroz. Os dois contos, distanciados no contexto cultural e temporal - o primeiro de 1958 e o segundo de 1895 -, apresentam essa temática de forma muito distinta graças aos recursos estilísticos empregados e às concepçóes estéticas ligadas à criaçáo artística e ao recurso fantástico subjacente. Ao longo da análise objetivamos discutir essas questôes, em especial a falta de consenso por parte da crítica entre a definiçâo de fantástico enquanto gênero, ou subgênero (TODOROV, 1992), e gêneros (conceitos?) afins.

Em Introduçáo à literatura fantástica (1992), Todorov, ao mencionar a indicaçăo convencional da leitura do começo ao fim, da esquerda à direita, enfatiza o quanto esta convençâo é primordial em alguns gêneros, entre eles, o fantástico. Segundo o estudioso, nos textos fantásticos, é essencial que o leitor realize a leitura de forma contínua, sem saltos, para que haja o processo de identificaçáo deste com as personagens e, consequentemente, o efeito fantástico. Outrossim, destaca a importância da primeira leitura do conto:

“(...) a primeira e a segunda leitura de um conto fantástico provocam impressōes muito diferentes (muito mais que em outros tipos de contos); em realidade, na segunda leitura, a

identificaçăo já năo é possível, a leitura se converte indevidamente em metaleitura: o leitor vai assinalando os procedimentos do fantástico em lugar de deixarse envolver por seus encantos." (TODOROV, 1992, p. 48).

Năo se pode deixar de observar que Edgar Alan Poe, na segunda resenha sobre "Twice-told tales", de Nathanael Hawthorne, publicada em maio de 1842, defende a brevidade das narrativas para criar uma "unidade de efeito" que exerce certa impressâo no leitor. Poe chega a defender o conto como uma forma superior ao romance por essa possibilidade:

O conto oferece, em nossa opiniăo, o melhor campo para o exercício do mais nobre talento. É necessário apenas dizer a respeito disso que em quase todas as categorias de composiçăo a unidade de efeito ou de impressâo é um ponto da maior importância. 
Além do mais, está claro que esta unidade năo pode ser totalmente preservada em produçôes cuja leitura nâo possa ser feita de uma assentada. (...) Referimo-nos à narrativa em prosa curta, que exige de meia hora até uma ou duas horas de leitura atenta. O romance comum tem suas objeçóes, devido à sua extensáo, pelos motivos já citados em destaque. Como năo pode ser lido numa assentada, perde, é claro, a imensa força derivada da totalidade. (...) No conto breve, no entanto, o autor pode levar a cabo a totalidade de sua intençăo, seja ela qual for. Durante a hora de leitura, a alma do leitor está nas máos do escritor. (POE, 2004, p. 4).

Consideramos que esse efeito no leitor, quando se trata do fantástico, é decorrente năo somente da concisâo, da identificaçăo entre leitor e narrador ou da hesitaçâo postuladas por Todorov, mas também de outros aspectos, como discutiremos adiante; no entanto, essa proposiçấo de Poe exemplifica como a reflexăo sobre esses recursos esteve presente no século XIX. Eça de Queirós (1958), por exemplo, também defende a brevidade e a sugestividade na escrita de contos e propóe a composiçăo interativa entre elementos narrativos buscando a concisâo na linguagem semanticamente intensificada que funciona como uma impressăo, um sentido encoberto instaurado pela voz narrativa de maneira sutil, ou seja, a arquitetura narrativa funciona como arcabouço de sustentaçâo do sentido implícito sempre presente.

Comecemos, pois, a análise pelo sucinto conto de Lygia F. Telles: uma barca, quatro personagens, uma atmosfera silenciosa, sombria e solitária. Eis a ambientaçâo inicial. Na noite de Natal, um velho bêbado, uma jovem mâe, um bebê e a personagem narradora dividem uma pequena embarcaçăo na travessia de um rio próximo à cidade de Lucena na Paraíba. A narrativa apresenta uma imagem desolada: "Ali estávamos os quatro, silenciosos como mortos num antigo barco de mortos deslizando na escuridāo." (TELLES, 1981, p. 103). Inevitável náo ocorrer à lembrança o barco de Caronte carregando as almas dos mortos pelo rio Estinge. Entretanto, como que para iniciar o desenrolar da narrativa e contrariar essa perspectiva fúnebre, a narradora pondera: "Contudo, estávamos vivos. E era Natal." (TELLES, 1981, p. 103). A escolha do número quatro, como se verá adiante, é significativa, pois segundo o Dictionnaire des symboles (CHEVALIER; GHEERBRANT, 1982, p.793), este "é o número da espera, de preparaçăo, de teste ou de puniçâa". ${ }^{3}$ Quatro também sâo os pontos cardeais, quatro săo as fases da lua e as estaçóes do ano que simbolizam o ciclo de nascimento, maturidade, declínio e renascimento da natureza e também das fases de vida do homem: nascimento, infância, maturidade e velhice. E năo se pode deixar de salientar que quatro săo as pontas da cruz, cujo simbolismo relaciona-se ao sacrifício de Cristo, à morte e renascimento para uma nova vida.

Um comentário fortuito sobre a frieza da água serve como gatilho para o diálogo que se estabelece entre a mulher que segura a criança e a personagem narradora. Em pouco tempo, esta fica sabendo que o filho da jovem está doente e precisa ser levado ao médico, que ela perdera o primeiro filho em uma queda e também que fora abandonada pelo marido. A esta altura, a interlocutora admira a resignaçáo da máe, diante de tantas adversidades:

Ia contando as sucessivas desgraças com tamanha calma, num tom de quem relata fatos sem ter realmente participado deles. Como se năo bastasse a pobreza que espiava pelos remendos da sua roupa, perdera o filhinho, o marido, via pairar uma

3 “c 'est le nombre de l 'attente, de la préparation, de l'épreuve ou du châtiment". Traduçăo nossa. 
sombra sobre o segundo filho que ninava nos braços. Eali estava sem a menor revolta, confiante. Apatia? Náo, náo podiam ser de uma apática aqueles olhos vivíssimos, aquelas máos enérgicas. Inconsciência? Uma certa irritaçáo me fez andar.

- A senhora é conformada.

- Tenho fé, dona. Deus nunca me abandonou.

- Deus - repeti vagamente.

- A senhora năo acredita em Deus?

- Acredito - murmurei. E ao ouvir o som débil da minha afirmativa, sem saber por quê, perturbei-me. Agora entendia. Aí estava o segredo daquela segurança, daquela calma. Era a tal fé que removia montanhas... (TELLES, 1981, p. 106).

Esta fé havia sido reforçada quando, após a morte do primogênito, a jovem măe entâo desconsolada - tivera um sonho incomum. Depois de muito chorar e implorar que seu filho fizesse a mágica de lhe aparecer só mais uma vez, ela dorme no banco de um jardim, sonha com o filho brincando com o Menino Jesus e tem seu último encontro tâo almejado. Acorda, assim, extremamente emocionada e feliz. Diante da convicçáo da mâe, em oposiçấo à sua incerteza, a narradora fica sem saber o que dizer e levanta o xale para olhar a criança nos braços da jovem: "Deixei cair o xale novamente e voltei-me para o rio. O menino estava morto. Entrelacei as măos para dominar o tremor que me sacudiu. Estava morto. A măe continuava a niná-lo, apertando-o contra o peito. Mas ele estava morto." (TELLES, 1981, p. 107).

Após a fatídica constatação do falecimento do bebê, a narradora é tomada por tremenda angústia perante a horrível e eminente descoberta da fatalidade pela mâe da criança. Conforme, podemos perceber no trecho abaixo:

Debrucei-me na grade da barca e respirei penosamente: era como se estivesse mergulhada até o pescoço naquela água. Senti que a mulher se agitou atrás de mim.

- Estamos chegando - anunciou.

Apanhei depressa minha pasta. O importante agora era sair, fugir antes que ela descobrisse, correr para longe daquele horror. Diminuindo a marcha, a barca fazia uma larga curva antes de atracar. O bilheteiro apareceu e pôs-se a sacudir o velho que dormia:

- Chegamos!... Ei! Chegamos!

Aproximei-me evitando encará-la.

- Acho melhor nos despedirmos aqui - disse atropeladamente, estendendo a máo.

Ela pareceu náo notar meu gesto. Levantou-se e fez um movimento como se fosse apanhar a sacola. Ajudei-a, mas ao invés de apanhar a sacola que lhe estendi, antes mesmo que eu pudesse impedi-lo, afastou o xale que cobria a cabeça do filho.

- Acordou o dorminhoco! E olha aí, deve estar agora sem nenhuma febre. 
- Acordou?!

Ela sorriu:

- Veja...

Inclinei-me. A criança abrira os olhos - aqueles olhos que eu vira cerrados tăo definitivamente. E bocejava, esfregando a măozinha na face corada. Fiquei olhando sem conseguir falar. (TELLES, 1981, p. 107).

O que se seguiu, entretanto, surpreendeu a personagem narradora, bem como o leitor envolto pela narrativa insólita de Lygia F. Telles. Estava instalado o "efeito de estranhamento" próprio da literatura de que nos fala Chklovski (1970) e, sobretudo, estava instaurado o efeito fantástico, expressăo utilizada por diferentes teóricos da literatura fantástica, entre os quais: Jean Bellemin-Noël (1972), Tzvetan Todorov (1992) e David Roas (2014). Nâo obstante as particularidades sutis de cada um pertinentes a este termo, o "efeito fantástico" concentra o sentido de provocar uma inquietaçâo diante da eclosâo de um fenômeno que nâo pertence à noçăo de realidade socialmente aceita e que, no entanto, ali está; como diz a personagem de Jorge Luis Borges, no conto "Livro de Areia", perante um livro de páginas infinitas: “Nâo pode ser, mas é." (BORGES, 2009, p. 102).

Todorov (1992), analisando principalmente narrativas fantásticas no século XIX, postulou a exigência de o fantástico ocorrer somente quando a hesitaçăo sobre a ocorrência ou náo ocorrência de um fato sobrenatural permanecer na perspectiva do personagem implicado na narraçăo. Dessa forma, classificou em subgêneros circunvizinhos, estranho e maravilhoso, os textos em que há uma explicaçāo para a transgressāo das leis físicas. No primeiro, os relatos cuja explicaçâo resolve-se por uma explicaçăo lógica e racional, no segundo, quando o sobrenatural é aceito como natural em um mundo regido por outras leis.

Porém, essa transgressáo nâo se apresenta mais como no século XIX, quando prevalecia uma compreensăo positivista dos fenômenos e o fantástico provocava medo e terror por propiciar a insegurança diante do que se considerava concreto e certo. $\mathrm{O}$ desenvolvimento científico do século XX demonstrou a impossibilidade de se acreditar em uma realidade única e imutável, que passou a ser vista como indecifrável e incerta, por nâo haver mais uma maneira correta de compreendê-la. O mundo passou a ser relativo e incerto frente a inexistência de verdades gerais e absolutas; portanto, parece năo mais haver um modo de transgredir essa incerteza. $O$ fantástico segue esse movimento e passa a ser repensado por se caracterizar sempre por uma relaçáo dialética com o real, acompanhando as mudanças estabelecidas na compreensăo de realidade do senso comum. Para David Roas, em um cotidiano em que năo há certezas absolutas, a tensâo entre realidade concreta e fenômeno meta-empírico é colocada em outra perspectiva, porque o fantástico contemporâneo coloca:

A irrupçăo do anormal em um mundo aparentemente normal, mas náo para demonstrar a evidência do sobrenatural, e sim para postular a possível anormalidade da realidade, o que também impressiona o leitor terrivelmente: descobrimos que nosso mundo năo funciona tăo bem quanto pensávamos (...) (ROAS, 2014, p. 67).

Essa perspectiva coaduna-se com a produçâo de Lygia F. Telles que, geralmente, é construída a partir da análise da personagem em relaçăo ao seu entorno e sua vivência, rememorada ou nâo, com um final surpreendente. A açăo é desenvolvida em favor da 
interioridade das personagens e a utilizaçăo da sugestividade e do insólito possibilita que o leitor tire suas próprias conclusóes, tendo em vista que o narrador náo oferece respostas prontas. A escritora, em consonância com a escrita contemporânea, privilegia a sugestăo, suas narrativas nâo săo arquitetadas com objetividade óbvia; pelo contrário, exigem um leitor atento e crítico para deslindar os sentidos implícitos e chegar à compreensâo mais profunda. O recurso estético utilizado é a "arte da alusăo" ou "arte da elipse", isto é, a narrativa é construída pelo amálgama entre elementos ocultos e perceptíveis à trama que acabam por emergir e se revelar. Esta tensăo entre o oculto e o explícito, beleza das narrativas lygianas, está ligado à proposta de Ricardo Piglia sobre o conto. De acordo com essa concepçấo, a forma do conto clássico é dupla, pois sempre conta duas histórias:

A arte do contista consiste em saber cifrar a história 2 nos interstícios da história 1. Um relato visível esconde um relato secreto, narrado de um modo elíptico e fragmentário. $\mathrm{O}$ efeito de surpresa se produz quando o final da história secreta aparece na superfície. (PIGLIA, 2004, p. 89).

Segundo explicita o teórico, o conto clássico utiliza estratégias que buscam criar o enredo implícito de maneira cifrada no primeiro. O fundamento da construçáo apoia-se na interseçâo entre os enredos. Por outro lado, Piglia considera que o conto moderno raramente apresenta um final surpreendente, porque procura trabalhar a "tensâo entre as duas histórias sem nunca resolvê-la. A história secreta é contada de um modo cada vez mais elusivo". (PIGLIA, 2004, p. 91). No caso de Lygia, admiradora de Poe, contista considerado "clássico" pelo estudioso argentino, esta questáo é mais complexa, o caráter evasivo da narrativa e a ambiguidade característica năo impedem que os desfechos sejam surpreendentes, especialmente quando săo contos pertencentes ao fantástico e suas variaçōes.

Ressaltamos que o insólito na produçăo da escritora, e de muitos autores contemporâneos, năo é necessariamente caracterizado por um acontecimento meta-empírico, como a técnica lygiana geralmente se constrói a partir de narraçóes em primeira pessoa, em que o narrador é ao mesmo tempo personagem, todo o enredo depende das certezas ou incertezas dessa perspectiva. Assim, a dúvida, a fragmentaçāo e a interioridade do narrador diante das questóes inquietantes ou cotidianas determinam as informaçôes dadas ao leitor que, ao final, deve decifrar a leitura da história 2, aquela implícita construída nas entrelinhas da história 1 (PIGLIA, 2004), preenchendo as lacunas com suas deduçôes. No conto em questâo, após o choque e estupefaçáo diante do desfecho surpreendente, o leitor deve, auxiliado pelas "informaçóes", isto é, pelos indícios e simbolismos presentes no texto literário, completar sua leitura e definir se a narradora presenciou, ou năo, um milagre.

A literatura do insólito, nomenclatura mais recente criada para abranger vários subgêneros: o maravilhoso, o fantástico, o estranho, o gótico, o realismo-maravilhoso, dentre outros, sempre exerceu inquestionável atraçăo no público leitor - seja por incitar um "medo" catártico, seja por atiçar a curiosidade diante do mistério, diante do que ultrapassa o "real" conhecido, ou ainda, diante das nossas concepçóes de realidade. Sobre o insólito, esclarece o professor Flávio Garcia:

(...) os eventos insólitos seriam aqueles que nâo săo frequentes de acontecer, sâo raros, pouco costumeiros, inabituais, inusuais, incomuns, anormais, contrariam o 
uso, os costumes, as regras e as tradiçóes, enfim, surpreendem ou decepcionam o senso comum, às expectativas quotidianas correspondentes a dada cultura, a dado momento, a dada e específica experienciaçâo da realidade. (GARCIA, 2007, p. 19).

Em consonância com essa concepçăo, a narrativa lygiana prepara o terreno para a irrupçăo do insólito desde o início da narraçăo com o mistério enunciado: "Nâo quero nem devo lembrar aqui por que me encontrava naquela barca. Só sei que em redor tudo era silêncio e treva. E me sentia bem naquela solidăo." (TELLES, 1981, p.103). Ela nâo quer se lembrar do motivo de estar naquele lugar no dia de Natal, mas se sentia bem.

Conforme dissemos, o número quatro aponta para um sentido simbólico que é reafirmado, em seguida, pelas oposiçóes apresentadas: quatro personagens "como mortos", mas "vivos"; o rio, ligado ao simbolismo da água, fonte da vida que flui, cuja temperatura, na noite escura, é fria segundo a narradora, mas é descrita como quente e verde pela jovem com a criança. Esse é o mote para a conversa entre as personagens que esclarece a fé inabalável da mâe e também coloca em pauta os mistérios sobrevindos. Graças a essa convicçăo, a jovem năo havia sucumbido diante de tantos infortúnios vividos. Esta certeza também possibilitara a mescla entre sonho e realidade, pois, graças ao sonho com o filho primogênito brincando com Jesus, ela acredita ter vivenciado uma bençăo, a presença real do menino falecido.

O conto constitui uma narrativa breve; todavia, tal concisâo de forma alguma apouca a riqueza de leituras e de interpretaçóes possíveis do conto. 0 espaço e o tempo da narrativa estăo desde logo explícitos no título, porém, constatamos a presença marcante de um subjetivismo espaço temporal remetendo a um tempo năo cronológico. A barca, que na mitologia greco-latina também era o meio de transporte usado pela travessia dos mortos, agrega ao relato escrito no século XX essa carga semântica de "passagem". O próprio rio - cuja água era "escura e fria" de noite, porém, "'verde e quente" de dia - afigura-se como elemento de renovaçăo. Há, contudo, referências espaciais relativas ao mundo objetivo: "- Mas a senhora mora aqui perto? - Em Lucena." (TELLES, 1981, p. 104). Essa mescla constrói a ocorrência de um "espaço híbrido", conforme terminologia de Felipe Furtado (1980), próprio da narrativa fantástica e formado por componentes "realistas" e "alucinantes". Em "Natal da barca", há um ambiente - ainda que pragmático - assaltado por expressôes como "em redor tudo era silêncio e treva", "luz vacilante", "nuvens tumultuadas". O tempo da diegese, por um lado, encontra-se definido como sendo uma noite de Natal; por outro, náo é possível inferir exatamente a duraçăo da viagem que é feita pelos passageiros. Dessa maneira, percebemos no texto a marca da incerteza relativa às noçôes de tempo e espaço.

Outro aspecto a fortalecer essa incerteza é a narraçăo em primeira pessoa. A partir da personagem narradora, sâo transmitidas as impressôes, os receios e a inquietude perante os acontecimentos do relato; ou seja, nâo há certeza absoluta, mas uma perspectiva subjetiva năo onisciente.

Vale considerar também que a experiência narrada pela máe que perdera o primeiro filho constitui, por si só, uma micronarrativa dentro do conto e, simultaneamente, explica a procedência daquela fé inabalável. Para a jovem - que, naquele momento, assume temporariamente a voz narrativa - o encontro com seu filho năo fora apenas um sonho, mas um episódio real. Tal incidente, que deixa a narradora (inicialmente) sem palavras, contrasta diretamente com o evento que se segue; ou seja, a constataçâo 
da morte (ou da suposta morte) do segundo filho, nos braços da máe, pela personagem narradora. Como já foi exposto anteriormente, após a infeliz descoberta, a narradora (assim como o leitor) passa por minutos angustiantes, era preciso fugir da dor inimaginável que a pobre măe sofreria.

Estes acontecimentos preparam o leitor para o clímax da narrativa: o mundo sagrado, marcado claramente pelo título - Natal, nascimento do filho de Deus -, imiscui-se na realidade possibilitando que a narrativa harmonize a ocorrência do insólito no mundo cotidiano, isto é, do milagre ter acontecido. A viagem reafirma a demanda pelo sagrado na busca de cura para o caçula. A barca era conhecida por aquela măe, outras vezes já a tomara, embora tenha sido surpreendida por precisar estar ali justamente no dia de Natal, tinha muita fé; portanto, a confiança certa de que Deus a abençoaria na necessidade, de que seu filho estava a salvo:

- [...] Já tomei esta barca náo sei quantas vezes, mas năo esperava que justamente hoje... [...]

- É. Esta doente, vou ao especialista, [...] Ainda ontem ele estava bem, mas de repente piorou. Uma febre, só febre... Levantou a cabeça com energia. 0 queixo agudo era altivo, mas o olhar tinha a expressăo doce. - Só sei que Deus năo vai me abandonar. (TELLES, 1981, p. 104).

Afinal, o inesperado acontece: a criança acorda, acorda? Estava apenas dormindo? Mas a narradora foi categórica, afirmou três vezes que o menino estava morto. Teria ele ressuscitado? Estava até "corado" e provavelmente curado... Será? O que de fato acontecera? É possível responder a essas questóes? Na verdade, nâo. O conto encerra e a incerteza permanece. No entanto, a cor verde do rio e seu simbolismo, esclarecidos por Chevalier e Gheerbrant, suportam nossa leitura:

Equidistante do azul celeste e do vermelho infernal, os dois absolutos e inacessíveis, o verde, valor médio, mediador entre quente e frio, alto e baixo, é uma cor reconfortante e refrescante, humana. [...]

O verde é a cor do reino vegetal se reafirmando, dessas águas regenerativas e lustradas, às quais o batismo deve todo o seu significado simbólico. 0 verde é o despertar das aguas primordiais, o verde é o despertar da vida." (CHEVALIER; GHEERBRANT, 1982, p.1002). ${ }^{4}$

A viagem iniciática pelo rio modifica o estado de espírito da narradora. $O$ verde das águas, anunciado pela jovem, simboliza o renascimento reforçado pela data mais importante para os cristăos - o nascimento do salvador da humanidade. No início, a narradora estava pessimista, lúgubre e descrente; porém, após sentir a força da fé demonstrada pela mâe do menino e vê-lo acordar depois de considerá-lo morto, é afetada profundamente. A crença presenciada contagia seu interior e transforma a realidade em seu entorno, enchendo-a de esperança:

4 Équidistant du bleu céleste et du rouge infernal, tous deux absolus et inaccessibles, le vert, valeur moyenne, médiatrice entrele chaud er le froid, le haut er le bas, est une couleur rassurante, rafraichissante, humaine. [...] Vert est la couleur du régne végétal se réaffirmant, de ces eaux régénératrice et lustrales, auxquelles le baptême doit toute sa signification symbolique. Le vert est l'éveil des eaux primordiales, vert est l'éveil de vie. (CHEVALIER; GHEERBRANT, 1982, p.1002). Traduçăo nossa e grifo dos autores. 
Fiquei olhando sem conseguir falar. [...] Encarei-a. Sob o manto preto, de pontas cruzadas e atiradas para trás, seu rosto resplandecia. Apertei-lhe a máo vigorosa. [...]

Saí por último da barca. Duas vezes voltei-me ainda para ver o rio. E pude imaginá-lo como seria de manhá cedo: verde e quente. Verde e quente. (TELLES, 1981, p. 108).

A história 2, de transformaçâo interior da personagem narradora, emerge sutilmente entremeada à história 1, a da mâe que viaja na barca para levar o filho doente ao médico. A certeza que transforma a realidade e promove a presença do insólito depende da visăo interior de cada um - personagens e leitor. Para a modernidade, pensada aqui como um nome genérico para o modo de ver e sentir do homem contemporâneo, o que existe é o que se acredita. Se nâo há verdades absolutas, o que poderia ser, o impossível sonhado, instala-se no cotidiano pela força do desejo ou da crença. Assim, cada um pode perscrutar o conto de Lygia Fagundes Telles e dar sua própria explicaçấo para a ocorrência ou năo do insólito, apresentado de forma mais aberta e inclusiva que o milagre cristăo, apesar da intertextualidade apontada. Năo por acaso a pesquisadora Irène Bessière (2009) nomeia a literatura fantástica como a "poética da incerteza".

\section{O MARAVILHOSO CRISTÃO TRADICIONAL E A PERSPECTIVA MODERNA}

Assim como a narrativa analisada, o conto "O defunto", do português Eça de Queirós, tem como temática o milagre e está relacionado à questâo do insólito, ainda que se diferencie daquele quanto ao subgênero e contexto inerente - como veremos mais adiante. Para adentrarmos a narrativa de Eça, faz-se necessário um recuo no tempo, mais precisamente para o ano de 1474. A história desenrola-se na cidade de Segóvia na Espanha e relaciona-se à vida (ou à morte) de quatro personagens: D. Alonso de Lara, D. Leonor (senhora de Lara), D. Rui de Cárdenas e um defunto enforcado; além destes, destaca-se ainda a figura de Nossa Senhora do Pilar - madrinha e interventora de D. Rui de Cárdenas. A referência a uma data específica e nomes da época, como Henrique IV, rei durante o final da Idade Média, cria, por um lado, uma ilusâo de realidade histórica sobre a narrativa, por outro, traz à baila as crenças e mistérios que dividiam espaço com a realidade da época, conforme esclarece o historiador Jacques Le Goff (1994), a respeito da formaçăo do imaginário cristăo que foi consolidado aos poucos pela Igreja, a partir da mistura de diversas culturas pré-cristăs. ${ }^{5}$

Na primeira das cinco partes que compóem o conto, temos a caracterizaçăo das três personagens de um póstero triângulo, nâo exatamente amoroso. Próximo à Igreja de Nossa Senhora do Pilar, passou a morar o jovem cavaleiro, "de gentil parecer", D. Rui de Cárdenas, tendo como vizinhos o velho e rico fidalgo D. Alonso de Lara (extremamente ciumento) e sua jovem e bela esposa D. Leonor. Sendo afilhado e devoto de Maria, D. Rui frequentava diariamente a Igreja e foi inevitável que se deparasse certa manhá de domingo com a também fiel devota de Nossa Senhora, D. Leonor:

5 Os imaginários, segundo a perspectiva da História Nova, sâo formas próprias de os homens verem o mundo e a si mesmos, criam e mantêm grupos e despertam a consciência social. Segundo Franco Júnior (2003), ao expressar valores coletivos, propiciam aos homens a certeza de pertencerem ao seu momento e à história. Os imaginários, portanto, nascem, vivem e morrem segundo a necessidade de compreensâo do mundo de uma dada sociedade e, por isso, nấo devem ser confundidos com a atividade psíquica pessoal da imaginaçăo que é individual. 
(...) essa curta visita a Nossa Senhora do Pilar bastou para que D. Rui se enamorasse dela tresloucadamente, na manhá de Maio em que a viu de joelhos ante o altar, numa réstia de sol, aureolada pelos seus cabelos de ouro, com as compridas pestanas pendidas sobre o livro de Horas, o rosário caindo de entre os dedos finos, fina toda ela e macia, e branca, de uma brancura de lírio aberto na sombra, mais branca entre as rendas negras e os negros cetins que à volta do seu corpo cheio de graças se quebravam (...). Quando depois dum momento de enleio e de delicioso pasmo se ajoelhou, foi menos para a Virgem do Pilar, sua divina Madrinha, do que para aquela apariçăo mortal, de quem năo sabia o nome nem a vida, e só que por ela daria vida e nome, se ela se rendesse por tăo incerto preço. (QUEIRÓS, s.d., p. 804).

Entretanto, a paixăo arrebatadora de D. Rui năo era correspondida. D. Leonor nem percebia os olhares ardentes do jovem apaixonado. Assim, transcorridas semanas de sofrimento, D. Rui terminou por desistir daquele desejo inalcançável, solicitando, para ambos, a bençăo de sua santa madrinha.

Na segunda parte da história, a velha aia, "com olhos de coruja", que sempre acompanhava, ou melhor, escoltava D. Leonor - assim como mais dois lacaios - revelou a D. Alonso o ousado interesse do jovem vizinho pela senhora de Lara. Já desconfiado, o fidalgo furioso manda vigiar D. Rui e D. Leonor e a proíbe de ir à Igreja. Ante o descaso percebido no moço vigiado, o marido ciumento queda-se, na verdade, com mais suspeitas e decide ir para sua propriedade de Cabril. Lá obriga a esposa a escrever uma carta de amor endereçada ao rapaz com o fito de lhe preparar uma cilada fatal. Surpresa, amedrontada e ameaçada, a jovem obedece. Porém, percebendo a sinistra intençăo do marido, lamenta a sorte do moço e roga proteçăo da Santa do Pilar.

A narrativa prossegue na terceira parte com D. Rui recebendo a carta, maravilhado, e dirigindo-se a Cabril, sem imaginar o plano funesto do marido. $O$ trajeto revela-se sobremodo incomum. Inicialmente, um turbilhăo de pensamentos e emoçóes passava no interior do moço enamorado que começou a sentir um "medo estranho", "o medo daquela felicidade (...) que lhe parecia sobrenatural. Era, pois, certo, que essa mulher de divina formosura, famosa em Castela, e mais inacessível que um astro, seria sua, toda sua (...)?" (QUEIRÓS, s.d., p. 813). Lamentava a efemeridade daquela ventura, mas estava cego de paixăo: "Que importava! Viessem depois dores e zelos! Aquela noite era esplendidamente sua, o mundo todo uma aparência vă e a única realidade esse quarto de Cabril, mal alumiado, onde ela o esperaria, com os cabelos soltos!" (QUEIRÓS, s.d., p. 813).

No caminho, chegando próximo a um arco, um mendigo - a quem D. Rui dera uma esmola - traz-lhe a lembrança de Nossa Senhora, entâo, o devoto desce do cavalo para rezar em frente a uma imagem da Santa que havia próximo ao velho arco. ${ }^{6}$ Retoma, pois, seu percurso e, após perder-se momentaneamente, recebe inesperada ajuda de uma velha que misteriosamente desaparece após lhe indicar o caminho correto.

Atingindo o "Cerro dos Enforcados" - local que servira como ponto de referência no itinerário até Cabril -, D. Rui depara-se com lúgubre visăo e, neste ponto, a narrativa aproxima-se do gótico tanto pela atmosfera penumbrosa, quanto pelo surgimento da figura grotesca do enforcado:

6 Importa destacar a devoção religiosa recorrente na narrativa, os devotos estão sempre requisitando o auxílio de Nossa Senhora, conforme é possível observar também na sequência. Essa concepção é característica da tradição medieval, especialmente o culto às diferentes manifestações de Maria na Península Ibérica. O costume de chamar a mãe de Cristo como "Nossa Senhora" exemplifica a proximidade dos fiéis 
(...) lá se erguiam, negros, enormes, sobre a amarelidăo do luar, os quatro pilares de granito semelhantes aos quatro cunhais duma casa desfeita. Sobre os pilares pousavam quatro grossas traves. Das traves pendiam quatro enforcados negros e rígidos, no ar parado e mudo. Tudo em torno parecia morto como eles.

Gordas aves de rapina dormiam empoleiradas sobre os madeiros. Para além, rebrilhava lividamente a água morta da lagoa das Donas. E, no céu, a Lua ia grande e cheia.

D. Rui murmurou o Padre-Nosso devido por todo o cristăo àquelas almas culpadas. Depois impeliu o cavalo, e passava - quando, no imenso silêncio e na imensa solidâo, se ergueu, ressoou uma voz, uma voz que o chamava, suplicante e lenta:

- Cavaleiro, detende-vos, vinde cá!...(QUEIRÓS, s.d., p. 815).

Parando e divisando aquele cenário deserto, o jovem, inicialmente, desconfia de seus sentidos. Contudo, ouve novamente o chamado vindo de um dos enforcados e, através do discurso indireto livre, cogita:

Restaria nalguns, por maravilhosa mercê de Deus, alento e vida? Ou seria que, por maior maravilha, uma dessas carcaças meio apodrecidas o detinha para lhe transmitir avisos de Além da Campa?... Mas que a voz rompesse dum peito vivo ou dum peito morto, grande covardia era abalar, espavoridamente, sem a atender e a ouvir. (QUEIRÓS, s.d., p. 815).

Assim, o destemido cavaleiro dirige-se aos corpos pendurados e trava diálogo com o enforcado que o chamara. A pedido deste, D. Rui corta a corda e visualiza mais de perto a face morta de seu interlocutor: "uma caveira com a pele muito colada, e mais amarela que a Lua que nela batia. Os olhos năo tinham movimento nem brilho. Ambos os beiços se lhe arreganhavam num sorriso empedernido. De entre os dentes, muito brancos, surdia uma ponta de língua muito negra." (QUEIROZ, s.d., p. 816). Em seguida, o enforcado declara que precisa seguir D. Rui até Cabril, deixando o cavaleiro estupefato. Nâo obstante sua repulsa inicial, o protagonista termina por acatar a proposiçáo como obra divina - depois que, cautelosamente, descarta possível açăo demoníaca.

Observando a reaçâo da personagem $\mathrm{D}$. Rui, notamos que, apesar de perceber o caráter extraordinário do fenômeno, o nobre jovem náo se desestabiliza. Aceita o fato de estar sendo acompanhado por um cadáver simplesmente por entender tudo isso como ordem de Deus, isto é, como um milagre divino. Essa reaçâo está de acordo com o modo de ver e sentir o mundo do homem medieval, cujo imaginário aceita a presença de forças extraordinárias na realidade quotidiana.

O significado de "maravilhoso" é explicado por Le Goff (1994) a partir de sua origem latina. Ao termo empregado hoje corresponde, na Idade Média, o plural mirabilia, cujo sentido fundamenta-se em imagens e metáforas relacionadas à visăo, embora as "maravilhas" nâo estejam limitadas somente a imagens que fazem arregalar os olhos, que sejam de admirar e espantar, porque "é todo um imaginário que se pode ordenar em volta desse apelo a um sentido, o da vista, e de uma série de imagens e de metáforas visuais." (LE GOFF, 1994, p.46).

A experiência do maravilhoso é uma reaçăo de espanto diante da incompreensibilidade do acontecimento, reflexo do deslumbramento causado pelo inexplicável 
manifesto naquele mundo, estabelecendo simultaneamente uma relaçăo de estranhamento e de cumplicidade, mas principalmente de aceitaçáo de sua existência.

O historiador explica que essa aceitaçăo do extraordinário, da presença do sobrenatural e do sagrado na vida humana está presente em diferentes culturas pré-cristăs, é uma herança cultural do Ocidente que a igreja católica tentou controlar, resultando em três subdivisóes: Mirabilis, Magicus e Miraculosus. Houve a necessidade por parte da igreja de delimitar a influência das antigas religiōes e tradiçóes, separando o que era aceito como intervençâo de Deus, o milagre, das consideradas superstiçôes ou intervençóes demoníacas. Assim o cristianismo oficial fez uma regulamentaçâo do maravilhoso (mirabilis), uma racionalizaçăo de um fenômeno que antes era múltiplo e imprevisível, e passou a ser controlado por um só Deus, que tem ajuda dos santos ou de Maria, segundo sua vontade. O que náo pôde ser atribuído a Deus foi relegado à magia (magicus). No início da assimilaçấo cristâ, do sincretismo, ainda havia a repartiçâo em magia branca (benigna) e magia negra (maligna), mas a ortodoxia acabou atribuindo ao demoníaco todo o sobrenatural náo miraculoso. Por fim, o sobrenatural miraculoso é chamado de maravilhoso cristáo (miraculosus).

O pesquisador francês também se refere à teorizaçăo de Todorov sobre o fantástico para explicar que o maravilhoso "tem a vantagem de ser um termo medieval cujo sentido e cuja história podem ser bem situados..." (LE GOFF, 1994, p. 32). Também destaca que o maravilhoso medieval difere do conceito de gênero literário por náo necessitar de um leitor implícito. Nos textos medievais, literários ou nâo, o maravilhoso é apresentado de forma natural e impessoal.

Por sua vez, o poeta e crítico M. M. de Mello e Castro, na Introduçáo a Antologia do conto fantástico português, explica que o fantástico tem contornos específicos em Portugal. O imaginário luso apresenta uma familiaridade com o sobrenatural, com suas possíveis interferências no mundo real, fruto da influência da religiosidade popular imiscuída de substratos pagáos anteriores ao cristianismo, como também da presença marcante do maravilhoso cristáo. Assim, a açáo do sobrenatural nos textos portugueses surge como um elemento harmonizador e corretivo:

Mas talvez essa certeza da existência e presença da sobrenaturalidade e da possível relaçáo com seres humanos, ou da interferência de diversos mundos, ou da năo diferença absoluta (mas apenas relativa), venha diretamente da influência medieval católica, e da realidade admitida antropomorficamente de uma corte celeste e uma tribo infernal, mafarricos e diabretes, etc., etc., influenciando para o bem ou para o mal a vida real dos homens portugueses. (CASTRO, 1974, p. XXI-XXII).

O năo estranhamento ou a convivência com seres de esferas distintas é um aspecto recorrente ao sobrenatural português. Fantasmas, demônios e outras entidades aliam-se aos humanos em busca de redençăo ou em troca de favores mútuos, como ocorre, por exemplo, em "Fradinho de mâo furada", de José da Silva, texto do início do século XVIII, filiado a uma tradiçâo muito antiga.

Após discutir essas características próprias da cultura portuguesa medieval que Eça de Queirós buscou recriar em seu conto - a retomada do medievo com intuito crítico nấo constitui novidade na produçấo do escritor - voltamos ao enredo deste no momento em que cavaleiro e defunto prosseguem na viagem até a propriedade de Cabril, atuando o segundo tal como guia e escudeiro do primeiro. 
Chegados à herdade do fidalgo, novo alvitre é lançado pelo enforcado: tomar o lugar de D. Rui e subir a escada que dava na direçâo da janela. Debalde o protagonista contesta ante tal disparate, rápido, o defunto lhe toma o sombreiro e a capa justificando-se: “- Năo mo negueis, senhor, que se vos fizer grande serviço, ganharei grande mercê!" (QUEIRÓS, s.d., p.818). E assim, o enforcado avança firme e indiferente à perplexidade de D. Rui que via aquela figura tomar-lhe mesmo sua própria aparência:

(...) - oh maravilha! - era ele, D. Rui, todo ele, na figura e no modo, aquele homem que, por entre os canteiros e o buxo curto, avançava, airoso e leve, com a măo na cintura, a face erguida risonhamente para a janela, a longa pluma escarlate do chapéu balançando em triunfo. 0 homem avançava no luar esplêndido. 0 quarto amoroso lá estava esperando, aberto e negro. E D. Rui olhava, com olhos que faiscavam, tremendo de pasmo e cólera. (...) - "Oh! lá sobe, o maldito!" rugiu D. Rui. O enforcado subia. Já a alta figura, que era dele, D. Rui, estava a meio da escada, toda negra contra a parede branca. Parou!... Nâo! náo parara: subia, chegava, (...) E eis que, de repente, do quarto negro surge um negro vulto, uma furiosa voz brada: - "vilăo, vilăo!" - e uma lâmina de adaga faísca, e cai, e outra vez se ergue, e rebrilha, e se abate, e ainda refulge, e ainda se embebe!... Como um fardo, do alto da escada, pesadamente, o enforcado cai sobre a terra mole. Vidraças, portadas do balcáo logo se fecham com fragor. (...)

Num relance D. Rui compreendera a traiçâo, arrancara a espada, recuando para a escuridăo da avenida - quando - oh milagre! correndo através do terraço, aparece o enforcado, que lhe agarra a manga e lhe grita:

- A cavalo, senhor, e abalar, que o encontro năo era de amor, mas de morte!.... (QUEIRÓS, s.d., p. 819).

Fogem entăo a cavalo, D. Rui e - para desespero deste - o defunto escudeiro atravessado pela adaga de D. Alonso. Retornando ao Cerro dos Enforcados, D. Rui, obediente à vontade divina, atende o último pedido singular de seu companheiro de enforcá-lo novamente. Em Segóvia, o cavaleiro dirige-se imediatamente à igreja de Nossa Senhora do Pilar para agradecer a intervençâo de sua madrinha e solicitar que seu inusitado salvador receba a mercê desejada.

Na quarta parte do conto, deparamo-nos com o senhor de Lara atarantado por nâo encontrar o corpo de D. Rui e completamente atônito ao vê-lo vivo andando nas ruas de Segóvia. Logo em seguida, D. Alonso fica sabendo do escândalo em torno do Cerro dos Enforcados:

Na véspera, de tarde, indo o corregedor visitar o cerro das forcas, pois se acercava a festa dos Santos Apóstolos, descobrira, com muito pasmo e muito escândalo, que um dos enforcados tinha uma adaga cravada no peito! Fora gracejo de um pícaro sinistro? Vingança que nem a morte saciara?... E para maior prodígio ainda, o corpo fora despendurado da forca, arrastado em horta ou jardim (pois que presas aos velhos farrapos se encontravam folhas tenras) e depois novamente enforcado e com corda nova!...(QUEIRÓS, s.d., p. 824).

O senhor de Lara parte entăo para o local a fim de verificar pessoalmente o caso e lá enxerga e constata, horrorizado, sua própria adaga cravada no enforcado. Perturbado, D. Alonso recolhe-se a Cabril e começa a definhar até um dia ser encontrado morto.

A quinta e última parte da narrativa, traz D. Leonor passando o período do luto no 
palácio de Segóvia. A partir desse momento, a jovem viúva dirige seus olhos para o cavaleiro D. Rui (que "escapara miraculosamente à emboscada de Cabril"). E ante o altar de Nossa Senhora do Pilar, "foram eles casados pelo bispo de Segóvia, D. Martinho, no Outono do ano da Graça de 1475". (QUEIRÓS, s.d., p. 825).

Em "O defunto", verificamos uma diegese linear, realizada por um narrador externo e onisciente, imersa em um cenário medieval. Nas duas primeiras partes do texto, a açâo desenvolve-se apresentando as personagens e suas correspondentes relaçóes, nas quais estâo presentes, entre outros, os temas do amor, da traiçâo, do ciúme e da devoçâo. A partir da terceira parte da história, o evento sobrenatural instala-se e interfere categoricamente no desenrolar dos acontecimentos. Afinal, D. Rui só sobrevive à cilada mortal graças à ajuda providencial do enforcado enviado por Nossa Senhora do Pilar.

Pela atmosfera macabra e mesmo pela figura sinistra (e teoricamente impossível) do defunto reanimado, o conto de Eça de Queirós aproxima-se do fantástico, sendo comumente assim classificado com a ressalva de que a cosmovisăo presente é a do maravilhoso cristâo temperada com doses do horrível gótico. Essa questăo salienta como classificaçóes ou subdivisóes de narrativas ligadas ao fantástico, como propôs Todorov, săo incompletas e permeadas por ressalvas. Daí a grande dificuldade de a crítica atual chegar a um consenso, visto que a arte é criativa e nâo se dobra a definiçôes. Apesar dessa discussâo conceitual que permeia o gênero fantástico, há um consenso entre a maioria dos estudiosos sobre a ocorrência de duas constantes essenciais na narrativa fantástica para que esta seja assim considerada: a primeira concerne ao surgimento de um evento aparentemente sobrenatural (ou de um fenômeno meta-empírico) em meio a nossa realidade empírica; a segunda, diretamente relacionada à primeira, diz respeito a uma inquietude, um estranhamento causado no leitor diante da incerteza do que seja real e possível, como salienta o estudioso David Roas, um dos efeitos do fantástico é "inquietar o leitor com a possibilidade do impossível." (ROAS, 2014, p. 158).

A filiaçăo da narrativa portuguesa ao maravilhoso cristăo, segundo a perspectiva literária, pode ser detalhada por Roas (2014, p. 37) como o "tipo de narraçăo de corte lendário e origem popular em que os fenômenos sobrenaturais têm uma explicaçáo religiosa (seu desenlace se deve a uma intervençăo divina)". De fato, várias referências sâo feitas à Virgem Maria, tanto D. Rui, como D. Leonor sâo devotos da santa, nâo há dúvidas quanto aos episódios sobrenaturais e, para D. Rui, tudo de insólito que acontece naquela noite, no Cerro dos Enforcados e em Cabril, justifica-se por meio da intervençăo de Nossa Senhora.

Este conto de Eça de Queirós filia-se à longa tradiçâo do culto mariano. Maria tem muitos nomes e títulos delineando algumas de suas funçôes no imaginário popular, desde topônimos de onde surgiu ou até relacionados a outros significados, como Nossa Senhora do Pilar: caracterizaçăo ligada ao seu aparecimento sobre um pilar a Sâo Tiago para que ele edificasse uma Igreja em seu nome após a conversăo da Espanha. Esta denominaçăo é a mais popular na Espanha por ser considerada o refugio dos pecadores, a consoladora dos aflitos. José Leite de Vasconcellos (1986), etnógrafo português, registra vinte e duas histórias que têm Maria como personagem principal na tradiçâo popular portuguesa. Desta presença marcante e de seus milagres nâo há indicaçôes na Bíblia. Salientamos também que as Cantigas de Santa Maria, compostas em galego-português no século XIII, se relacionam à tradiçăo dos milagres marianos, bastante 
antiga na Península Ibérica, além de exemplificar a mescla entre popular e erudito, sagrado e profano. Dentre os milagres realizados pela Virgem Maria há a ajuda a uma abadessa que engravidara, a proteçâo a uma freira que fugira do convento por um cavaleiro, e outras questóes ligadas ao pecado. A todos aqueles que lhe dedicam verdadeiro culto e fé, ela protege e auxilia (FARIA, 2009).

Por conta da questâo religiosa, segundo afirma Roas: "Nesse tipo de narrativa, o aparentemente fantástico deixaria de ser percebido como tal uma vez que se refere a uma ordem já codificada (neste caso, o cristianismo), o que elimina toda possibilidade de transgressāo" (ROAS, 2014, p. 37). E assim acontece na história de Eça, os acontecimentos săo inusitados, extraordinários; contudo, possíveis dentro da crença católica. Nâo há confronto, o real nâo é posto em questăo. Além disso, o conto também se coaduna a duas características comuns às narrativas do maravilhoso cristăo, ainda conforme o estudioso espanhol: "a ambientaçăo rural e a distância temporal dos fatos narrados" (ROAS, 2014, p. 38).

No artigo "A tensăo entre o fantástico e o maravilhoso", a professora Marcia Romero Marçal também analisa este subgênero literário, conferindo-lhe outra denominaçâo, embora discuta as características sobre a cultura portuguesa elencadas por Mello e Castro e citadas anteriormente:

(...) é interessante observar que no Fantástico português esta ambigüidade, assentada sobre a irredutibilidade entre o real e o sobrenatural, sobre uma concepçáo de realidade que expulsa qualquer possibilidade de intromissáo de fenômenos extranaturais, náo está presente. Isto se deve à herança histórica de um catolicismo medieval, no qual o natural e o sobrenatural participam de uma cosmovisăo em que estas esferas năo săo excludentes racionalmente. Racionalidade e sobrenatural năo correspondem a duas ordens contrárias irredutíveis e inconciliáveis para o imaginário católico medieval. Na cosmovisáo católica, o sobrenatural povoa a realidade prosaica do cotidiano, de certa forma, "naturalmente". Espíritos diabólicos, entidades de outro mundo, forças desconhecidas, do Além, fantasmas, monstros, assim como anjos, beatos, santos interferem na vida real sem que a razáo, ainda que aterrada pelo medo, sinta-se desalojada de suas propriedades constitutivas. Este tipo de narrativa sofre a classificaçâo de Fantástico religioso. (MARÇAL, 2009, p. 5-6, grifos nossos).

Essa ausência de tensăo entre a realidade e o fenômeno meta-empírico pode dificultar a inclusăo do conto no fantástico; porém, nâo impede que ele seja conceituado como pertencente à literatura do insólito, tendo em vista que os acontecimentos inusitados - um defunto enforcado voltar à vida para tomar o lugar do cavaleiro e ser alvo de uma emboscada sâo aceitos, mas năo deixam de ser percebidos como incomuns e extraordinários, frutos da intervençăo divina. Embora o recuo no período medieval e o mergulho no maravilhoso cristăo atenuem o efeito fantástico, a mescla de recursos ligados ao insólito delineia a maestria queirosiana: o espaço do Cerro dos enforcados, conforme dissemos, é caracterizado com laivos do gótico e macabro, assim como o defunto é descrito fisicamente de modo sinistro e horrível. Complementa essa questâo o deslocamento da atençâo, isto é, a ênfase do conto, seu título, destacar o fenômeno meta-empírico: o defunto.

Além disso, ressaltamos que essa crença nâo é comungada por todos os personagens da narrativa. O marido traído, o Senhor de Lara, năo consegue compreender os acontecimentos daquela noite misteriosa, ele racionaliza, busca explicaçôes e acaba 
enlouquecendo por năo imaginar a soluçăo segundo a perspectiva religiosa do milagre. Para ele o impossível náo poderia ter acontecido, por isso, acaba definhando e morrendo.

Ironicamente, na narrativa de Eça de Queirós, escritor considerado representante do estilo realista em Portugal, aquele que năo tem fé, que năo acredita no mistério por aceitar somente os fatos positivos, acaba perecendo. Assim, nesse conto a aceitaçâo do milagre, a ruptura da coerência racional, converte-se em uma forma subversiva de experimentar a realidade humana e transcendê-la. Ou seja, nesta narrativa o insólito funciona como uma reaçăo a um mundo em que a incerteza, o sobrenatural e a ambiguidade nâo têm mais espaço diante do racionalismo e do empirismo postulados pelas ciências. Por vir contra esta ordem estruturada, Eça de Queirós apresenta outra perspectiva - a religiosa - e uma indagaçăo humana diante da complexidade da vida nunca totalmente apreendida pelo empirismo científico. A partir do pressuposto de que a perspectiva fantástica utilizada pelo autor serve como meio de se repensar o real, consideramos que, neste conto, o autor critica a elite portuguesa, mergulhada em seus próprios interesses, que se afastara da verdadeira fé, da religiosidade vivenciada de maneira mais íntima e devotada.

\section{O MILAGRE NO TEXTO LITERÁRIO}

Como dissemos no início do presente trabalho, a tentativa de acompanhar a produçâo literária marcada pelo insólito consiste em tarefa desafiadora, uma vez que - embora já se encontrem delimitados alguns parâmetros relativos aos conceitos do fantástico e demais variaçóes literárias - deparamo-nos, por um lado, com uma teoria crítica, sobretudo, dinâmica focada sobre um território de incerteza e ambiguidade, delimitado por dicotomias que se imiscuem a despeito do conflito inerente: o real e o náo real, o sólito e o insólito, o natural e o sobrenatural. Por outro lado, a singularidade própria do texto literário, fundamentado na vocaçāo dialética de existir pela linguagem e "dizer mais do que diz a linguagem" (TODOROV, 1992, p.175), intensifica a questâo levando-nos a concordar com o teórico búlgaro quando, ao discutir a impressăo ambígua deixada pela literatura fantástica, define-a como "a quinta-essência da literatura, na medida em que o questionamento do limite entre real e irreal, característico de toda literatura, é seu centro explícito" (...) e também porque "combatendo a metafísica da linguagem cotidiana, ela lhe dá vida" (TODOROV, 1992, p.176).

Tais características obrigam o leitor a repensar o seu modo de ler/ver a realidade, denotando também a reflexâo e o questionamento por parte do autor. O recurso ao fantástico constitui uma estratégia de questionamento dialético da realidade com vistas à reflexâo que se abre a diversas possibilidades.

Por caminhar paralelo a este estudo crítico quase "movediço", é inevitável que - entre as possíveis certezas de nossas leituras e interpretaçóes - estejam, acima de tudo, as incertezas e os questionamentos. Desse modo, temos um conto bem próximo do chamado maravilhoso cristăo, porém, seria de todo equivocado năo considerar a presença de um efeito fantástico em "O defunto"? A narrativa de Lygia com certeza nâo se "enquadra" na definiçấo de fantástico formulada por Todorov, nem por Felipe Furtado, por exemplo; entretanto, texto sobremodo rico, condensa em poucas páginas uma leitura múltipla ligada à fé que "transporta montanhas", que transforma pessoas, 
ao evento insólito imerso no cotidiano, à abertura interpretativa e à proximidade do fantástico, seja este um gênero, um modo, um conceito, ou um efeito. A análise comparativa entre os dois contos delineia a relaçăo intrínseca entre a literatura fantástica e as concepçóes de realidade de cada contexto sócio temporal, assim como coloca em perspectivas essas modificaçôes, relacionando-as segundo a compreensăo da herança cultural religiosa profundamente imiscuída em nosso inconsciente. Ou seja, embora distintas quanto aos subgêneros literários (ainda năo totalmente definitivos, se é que um dia o serăo) e outros pontos acima já destacados, as narrativas "Natal na barca" e "O defunto", curiosamente, encerram alguns aspectos convergentes, em especial: a relaçăo antinômica de "vida e morte", a questăo da fé e, sobretudo, a manifestaçăo do milagre, estando - em verdade - todos relacionados entre si.

Quando analisadas em conjunto, aspectos do imaginário cristăo ocidental afloram favorecendo o entrecruzamento de possíveis leituras. A relaçấo da vida e da morte apresenta-se nos dois contos de forma contundente: no conto queirosiano, seja pelo morto que vive de novo, ainda que temporariamente, seja por D. Leonor que, de certa forma, passa a viver de fato ao encontrar o amor verdadeiro, após a morte de D. Alonso, seja por este último que, procurando a morte de D. Rui, termina por encontrar a própria. Da mesma forma, no conto lygiano, essa relaçáo é apresentada pela barca misteriosa transportando um velho (que já conversa com o invisível), uma mulher (que parece fugir da vida para depois dela se encantar novamente - voltando a viver a esperança), uma criança (cuja breve vida vacila) e uma máe (que já sentira a alegria de, por duas vezes, carregar outra vida dentro de si, que havia sido flagelada pela morte de uma dessas vidas e que, agora, póe toda a sua fé na vida que carrega nos braços).

Por fim, as temáticas da vida e da morte também estăo, sob ângulos diversos, relacionadas às noçôes de tempo no passado, presente e futuro.

Outrossim, observamos a presença da religiosidade em ambas as narrativas, mas, principalmente - verificamos a existência incontestável de uma fé verdadeira nos devotos de Nossa Senhora do Pilar e na pobre máe de "olhos extraordinariamente brilhantes", cujo "longo manto escuro" externava "caráter e dignidade". Tanto D. Leonor, quanto D. Rui solicitaram ajuda à santa do Pilar, por meio de suas preces, e foram auxiliados. Assim também, a jovem mâe conseguiu o "encontro" com seu primeiro filho, após comovente súplica, e finalizou o trajeto da barca olhando para a face corada do segundo filho.

Reanimaçăo de um cadáver, cura ou possível "ressuscitaçâo" de um bebê (dependendo da leitura), o fato é que o tema do milagre (imbricado às noçôes de vida, morte e fé) encontra-se representado, de forma substancial, nos contos aqui explorados; além disso, a questăo do milagre está essencialmente associada ao clímax dos dois enredos. Em "O defunto", o momento de maior intensidade da narrativa inicia-se com o surgimento do enforcado vivificado e atinge seu ápice justamente no momento crucial em que o defunto toma o lugar de $\mathrm{D}$. Rui recebendo, por este, o golpe de adaga dado por $\mathrm{D}$. Alonso. Já em "Natal na barca", o clímax tem início no segundo em que a personagem narradora percebe a "morte" da criança, intensifica-se com a expectativa de descoberta (desta possível morte) por parte da măe e encerra-se no instante em que, para surpresa da narradora, a criança desperta.

A propósito das consideraçōes acima, é interessante observarmos a colocaçăo de 
David Roas quando este - comparando o fantástico, o maravilhoso, o realismo-maravilhoso e o maravilhoso cristăo - destaca precisamente uma similitude entre o primeiro e o último, afirma o estudioso: “o 'maravilhoso cristăo' está construído em funçâo desse momento de revelaçấo final onde o milagre faz sua apariçấo (o que o aproxima da estrutura própria da narrativa fantástica 'pura')" (ROAS, 2014, p. 39). Ou seja, enquanto no maravilhoso e no realismo-maravilhoso os eventos insólitos, de certa forma, já fazem parte da realidade (ainda que sejam realidades distintas); no maravilhoso cristăo e no fantástico, os fenômenos meta-empíricos revelam-se de maneira inesperada e, geralmente, estăo ligados ao ápice da narrativa.

Ao confrontar duas narrativas por muitos aspectos divergentes e, ainda assim, ser-nos possível destacar, inclusive de maneira bastante profícua, semelhanças, leituras em comum e, mais do que tudo, conjecturar questionamentos, constatamos o quăo rica pode ser a peculiaridade do texto literário. Assim sendo, ambas as narrativas cativam, envolvem e surpreendem o leitor, cada uma a seu modo. Mesmo porque săo tempos, espaços, narradores, personagens e enredos diversos. A leitura em conjunto dos contos aqui analisados permite demonstrar a representaçăo simultânea do milagre enquanto tema e alcance literário. É o insólito na literatura e da literatura em uma açâo constante e contínua de fascinar e instigar cada vez mais o leitor fisgado.

\section{REFERÊNCIAS}

BELLEMIN-NOËL, Jean. Notes sur le fantastique: textes de Théophile Gautier. Littérature, Paris, n.8, p.3-23, 1972. Disponível em: <https://www.persee.fr/doc/ litt_0047-4800_1972_num_8_4_1051>. Acesso em: 21 jul. 2017.

BESSIÈRE, Irene. O relato fantástico: forma mista do caso e da adivinha. FronteiraZ. No. 03, jan/jun 2009, p.01-18.

BORGES, J. L. O Livro de areia. Traduçăo: Davi Arrigucci Jr. Săo Paulo: Companhia das Letras. 2009.

CHLOVSKI, V. A arte como procedimento. In: TOLEDO, D. Teoria da literatura: formalistas russos. Porto Alegre: Globo S. A., 1970, p.39-56.

FARIA, R. M. V. C. T. de. O conto popular português. 2009. 467 f. Tese (Doutorado em Literatura Portuguesa) - Pós-Graduaçăo em Letras: Universidade do Porto, Porto, 2009.

FRANCO JÚNIOR, H. O fogo de Prometeu e o escudo de Perseu. Reflexōes sobre mentalidade e imaginário. Signum. Săo Paulo, n. 5, 2003, p.73-116.

FURTADO, F. A construçâo do fantástico na narrativa. Lisboa: Livros Horizonte, 1980.

GAMA-KHALIL, M. M.. A literatura fantástica: gênero ou modo?. Terra Roxa e Outras Terras. Londrina, v. 26, nº. 1, p.18-31, dez. 2013. 
GARCIA, F. O "insólito" na narrativa ficcional: a questăo e os conceitos na teoria dos gêneros literários. In: A banalizaçâo do insólito: questōes de gênero literário - mecanismos de construção narrativa. Rio de Janeiro: Dialogarts, 2007, p.10-22.

GARCIA, F.; FRANÇA, J.; PINTO, M. (orgs.). Introduçăo. In: e o insólito ficcional. Rio de Janeiro: Caetés, 2013, p.9-10. As arquiteturas do medo

LE GOFF, J. O maravilhoso no Ocidente medieval. In: . O imaginário medieval. Lisboa: Estampa, 1994, p. 45-65.

MARÇAL, M. A tensăo entre o fantástico e o maravilhoso. Revista FronteiraZ, v. Eletrônico, n.3, p. 1-8, 2009. Disponível em: 〈https://revistas.pucsp.br/index.php/fronteiraz/article/view/12541/9111>. Acesso em: 12 jan. 2018.

PIGLIA, R. Formas breves. Trad. José Marcos Mariani de Macedo. Săo Paulo: Companhia das Letras, 2004.

POE, E. A. Resenhas sobre Twice-Told Tales, de Nathaniel Hawthorne. Traduçăo de Charles Kiefer. Bestiario, Porto Alegre, v.1, n.6, 2004. Disponível em: http://www.bestiario.com.br/6.html. Acesso em: 10 jan. 2018.

QUEIRÓS, E. O Defunto. In: Obras de Eça de Queiroz. Porto: Lello \& Irmăo Editores, s.d., v.1, p.803-825.

Prefácio dos Azulejos do Conde de Arnoso. In: . Obra Completa. Porto: Lello \& Irmăo Editores, 1958, vol. 2, p. 1430-1443.

ROAS, David. A ameaça do fantástico. Aproximaçōes teóricas. Traduçăo de Julián Fuks. Sâo Paulo: Unesp, 2014.

TELLES, L. F. Natal na barca. In: Mistérios. Rio de Janeiro: Nova Fronteira, 1981, p.101-108.

TODOROV, T. Introduçâo à literatura fantástica. Traduçâo de Maria Clara Correa Castello. 2. ed. Săo Paulo: Perspectiva, 1992.

VASCONCELLOS, José Leite. Tradiçóes populares de Portugal. Lisboa: Imprensa Nacional-Casa da Moeda, 1986.

Submetido em 21 de março de 2018 